\title{
Edukasi Optimalisasi Tumbuh Kembang Balita dalam Upaya Pencegahan Stunting
}

\author{
Mila Triana Sari ${ }^{1}$, Melda Amalia ${ }^{2 *}$ \\ ${ }^{1}$ Program Studi Ners, Sekolah Tinggi Ilmu Kesehatan Baiturrahim, Jambi \\ ${ }^{2}$ Program Studi DIII Kebidanan, STIKes Baiturrahim Jambi \\ email: melda.skb@gmail.com
}

Submitted : 13/04/2020

Accepted: $24 / 04 / 2020$

Published:16/06/2020

\begin{abstract}
Toddler health efforts are activities / work programs in the health sector that concern health services and maintenance for toddlers, namely children aged 12 months to 59 months with the aim of preparing a healthy, intelligent and quality generation while aiming to reduce infant mortality. Based on Lancet data (2012), 44.7\% of infant deaths were caused by low birth weight (LBW), failure to breastfeed, Stunting (short), underweight, and lack of vit A and Zink minerals. The MSG program is an effort to prevent the occurrence of stunting by combining several health education methods in one package consisting of conventional health education, distributing leaflets and PMTS as well as training mothers to detect early toddlers at home. This effort is carried out at the basic service level, namely the puskesmas and its working area. The implementation method is divided into 3 stages: the preparation, implementation, monitoring and evaluation stages. Conclusion: all toddlers are in the category of good nutrition, Mothers of toddlers finally know the importance of measuring the growth and development of toddlers, toddlers mothers know the importance of preventing stunting in infancy
\end{abstract}

Keywords: the growth and development, toddler, stunting

\begin{abstract}
Abstrak
Upaya kesehatan balita merupakan kegiatan/program kerja di bidang kesehatan yang menyangkut pelayanan dan pemeliharaan kesehatan pada balita yaitu anak yang berusia 12 bulan sampai dengan 59 bulan dengan tujuan mempersiapkan generasi yang sehat, cerdas dan berkualitas sekaligus bertujuan untuk menurunkan angka kematian balita. Berdasarkan data Lancet (2012) sebanyak 44,7 \% kematian bayi disebabkan karena berat bayi lahir rendah(BBLR), kegagalan pemberian ASI, balita Stunting (pendek), kurus, dan kekurangan vit A dan mineral Zink. Program MSG merupakan upaya pencegahan kejadian stunting dengan mengkombinasikan beberapa metode penyuluhan kesehatan dalam satu paket terdiri dari penyuluhan kesehatan secara konvensional, pembagian leaflet dan PMTS serta melatih ibu untuk mendeteksi dini balitanya dirumah. Upaya ini dilakukan di tingkat pelayanan dasar yaitu puskesmas dan wilayah kerjanya. Metode pelaksanaan dibagi 3 tahapan yakni: tahap persiapan, pelaksanaan, monitoring dan evaluasi. Kesimpulan: semua balita termasuk alam kategori gizi baik, Ibu balita akhirnya mengetahui pentingnya pengukuran pertumbuhan dan perkembangan balita, ibu balita mengetahui pentingnya mencegah stunting pada masa balita.
\end{abstract}

Kata kunci: balita, pertumbuhan dan perkembangan, stunting

\section{PENDAHULUAN}

Upaya kesehatan balita merupakan kegiatan/program kerja di bidang kesehatan yang menyangkut pelayanan dan pemeliharaan kesehatan pada balita yaitu anak yang berusia 12 bulan sampai dengan 59 bulan dengan tujuan mempersiapkan generasi yang sehat, cerdas dan berkualitas sekaligus bertujuan untuk menurunkan angka kematian balita. Berdasarkan data Lancet (2012) sebanyak 44,7 \% kematian bayi disebabkan karena berat bayi lahir rendah(BBLR), kegagalan pemberian ASI, balita Stunting (pendek), kurus, dan kekurangan vit A dan mineral Zink. 
Laporan dari Riskesdas (2018), terdapat $17,7 \%$ balita mengalami berbagai masalah gizi buruk dan gizi kurang termasuk stunting $(30,8 \%)$ yang saat ini menunjukkan fakta yang memprihatinkan, dimana Indonesia termasuk dalam lima besar negara dengan prevalensi tertinggi di Asia Afrika. Sedangkan Provinsi Jambi prevalensi stunting $(30,1 \%)$. Berdasarkan data Dinas Kesehatan Provinsi Jambi Tahun 2018, persentase stunting tertinggi terdapat di Kabupaten Tanjung Jabung Barat (44\%) dan terendah di Kabupaten Sarolangun $(18,8 \%)$, untuk Kota Jambi angka kejadian Stunting (26.2\%). Sehingga dalam mengatasi stunting, masyarakat perlu diberikan pemahaman tentang pentingnya gizi bagi ibu hamil dan anak balita, yaitu dengan memberikan edukasi pada kelas ibu balita dengan program Mother Smart Grounding (MSG).

Program MSG merupakan upaya pencegahan kejadian stunting dengan mengkombinasikan beberapa metode penyuluhan kesehatan dalam satu paket terdiri dari penyuluhan kesehatan secara konvensional, pembagian leaflet dan PMTS serta melatih ibu untuk mendeteksi dini balitanya dirumah. Upaya ini dilakukan di tingkat pelayanan dasar yaitu puskesmas dan wilayah kerjanya.

Puskesmas Putri Ayu merupakan Puskesmas 1 dari 2 puskesmas perawatan yang ada di Kota Jambi. Puskesmas ini beralamat di Jalan Slamet Riyadi nomor 02 Kelurahan Legok Kecamatan Danau Sipin Kota Jambi. Wilayah Kerja Puskesmas Putri Ayu terdiri 5 kelurahan dengan 5 puskemas pembantu yaitu 1) Kelurahan Solok Sipin (Pustu Solok Sipin); 2) Kelurahan Murni (tidak memiliki pustu); 3) Kelurahan Sungai Putri (Pustu Sungai Putri); 4) Kelurahan (Pustu Legok dan Pustu Danau Sipin) dan; 5) Kelurahan Danau Sipin. Puskesmas Putri Ayu didirikan pada tahun 1968, saat ini memiliki tenaga kesehatan yang terdiri dari 2 orang dokter umum, 2 orang dokter gigi,
2 orang sarjana. Sebagai salah satu fasilitas pelayanan kesehatan, Puskesmas Putri Ayu memiliki 2 program utama yaitu Program Pokok dan Program Pengembangan Khusus. Program Pokok terdiri dari 5 yaitu: 1) promosi kesehatan; 2) kesehatan ibu dan anak; 3) gizi; 4) kesehatan lingkungan dan 5) pengobatan dasar. Program Pengembangan Khusus juga memiliki 5 program yaitu 1) upaya kesehatan lansia; 2) pelayanan perawatan kesehatan masyarakat (perkesmas); 3) upaya kesehatan mata; 4) upaya kesehatan jiwa; dan 5) upaya kesehatan telinga (Profil Puskesmas Putri Ayu Tahun 2017).

Untuk meningkatkan kesehatan ibu dan anak, PKM Putri Ayu mengembangkan kelas ibu balita, yaitu kelas ibu-ibu yang memiliki anak usia 12 bulan - 59 bulan, bersama-sama berdiskusi, terkait kesehatan balita, gizi dan stimulasi tumbuh kembang yang dibimbing oleh fasilitator menggunakan buku KIA yang dilaksanakan ditiap kelurahan. Survey awal yang dilakukan pada pelaksanaan kelas ibu balita berdasarkan hasil wawancara dengan fasilitator di PKM Putri Ayu, pelaksanaan lebih terfokus kepada peningkatan pengetahuan ibu, belum kepada ketrampilan, selain itu metode MSG belum optimal dilakukan, pelaksanaan juga belum sesuai modul berdasarkan usia balita.

Dari permasalahan mitra tersebut dapat diketahui bahwa, Puskesmas Putri Ayu telah melaksanakan kelas ibu balita terpadu sesuai dengan tugas dan peran puskesmas bagi masyarakat. Namun, pelaksanaan berbagai kegiatan tersebut belum maksimal dan masih memiliki keterbatasan baik dari pihak puskesmas maupun masyarakat sendiri. Berbagai permasalah tersebut merupakan masalah yang harus segera mendapat perhatian, oleh karena itu, tim pengabdian kepada masyarakat ini merasa perlu melakukan upaya promotif dan preventif melalui kegiatan penyuluhan kesehatan kepada ibu balita melalui metode 
MSG yang diberikan pada kegiatan Kelas Ibu Balita.

\section{METODE PELAKSANAAN}

Pengabdian masyarakat ini dilaksanakan pada bulan OktoberNopember 2019. Sasarannya adalah ibu yang memiliki balita yang berkunjung di Puskesmas Putri Ayu Kota Jambi. Metode pelaksanaan dibagi 3 tahapan yakni:

A. Tahap Persiapan

Kegiatan pada tahapan ini yakni sosialisasi pertemuan dengan petugas Puskesmas Putri Ayu dengan tujuan untuk menyamakan persepsi antara tim Pengabdian dengan Mitra (Puskesmas Putri Ayu). Rincian Kegiatan Sosialisasi sebagai berikut:

1. Perumusan Solusi dengan melakukan diskusi antara tim puskesmas dan tim pengabmas dengan tujuan identifikasi masalah baik melalui survey di Puskesmas, wawancara dengan beberapa ibu balita maupun petugas puskesmas

2. Tim Pengabmas menawarkan solusi kepada puskemas dan strategi dalam pelaksanaannya.

3. Tim Pengabmas menyiapkan alat dan bahan.

B. Pelaksanaan

Kegiatan meliputi tumbuh kembang,demonstrasi stimulasi, pengukuran TB/BB, LIKA LILA, pemenuhan gizi serta pemberian PMTAS. Kegiatan yang dilakukan pada tahap ini meliputi mengkaji pengetahuan awal ibu balita, edukasi pengetahuan ibu balita dengan menggunakan metode MSG, mengkaji sikap ibu balita, edukasi sikap ibu balita dengan menggunakan media KIE, demontrsasi stimulasi tumbuh kembang balita dan evaluasi kegiatan dengan melakukan post test.

C. Monitoring dan Evaluasi

Monitoring dan evaluasi dimulai dari perencanaan, pelaksanaan, hasil dan dampak yang dirasakan

\section{HASIL DAN PEMBAHASAN}

Menjelaskan dan menguraikan tentang: a) Pengukuran Tumbuh kembang Balita

Masa bayi dimulai dari usia 0-12 bulan, masa balita dimulai dari 12-60 bulan. Perkembangan pertumbuhan balita ditandai dengan perubahan fisik yang cepat serta perubahan kebutuhan zat gizi. Menurut supariasa (2001) pada dasarnya penilaian status gizi dapat dibagi dua yaitu secara langsung dan tidak langsung.

1. Penilaian status gizi secara langsung dapat dibagi menjadi empat penilaian yakni antropometri, klinis, biokimia, dan biofisik.

2. Penilaian status gizi secara tidak langsung dapat dibagi menjadi 3 bagian yakitu survey konsumsi makanan, statistic vital, dan faktor ekologi.

Cara pengukuran status gizi yang paling sering digunakan adalah antropometri gizi yakni dengan pengukuran dimensi tubh dan kompisoso tubuh dari bebagai tingkat umur dan tingkat gizi. Bebrbagai jenis ukuran tubuh antara lain, berat badan, tinggi badan, lingkar lengan bagian atasdan tebal lemak bagian bawah kulit. Keunggulan mudah dilakukan,dapat diukur berulang-ulang ( $\mathrm{ibu}$ sendiri dapt melakukan / tanpa petugas medis), biaya lebih murah, hasil dapat disimpulkan, dan secra ilmiah dapat diakui keberadaannya. ${ }^{3}$

Status gizi dapat diperoleh dengan pemeriksaan antropometri. Indikator yang digunakan berdasarkan depkes $(2010)^{4}$ adalah BB/u, TB/U, BB/TB, IMT/U, dengan klasifikasi status gizi berat badan per umur $(\mathrm{BB} / \mathrm{U})$ adalah sebagai berikut:

a. Gizi lebih, jika lebih dari 2,0 SD

b. Gizi baik , jika -2,0 SD sampai $+2,0$ SD

c. Gizi buruk, jika kirang dari $-3,0$ SD

Mayoritas ibu balita yang hadir dalam kegiatan pengabdian masyarakat memiliki 
balita berusia 24 bulan dan status gizi baik.

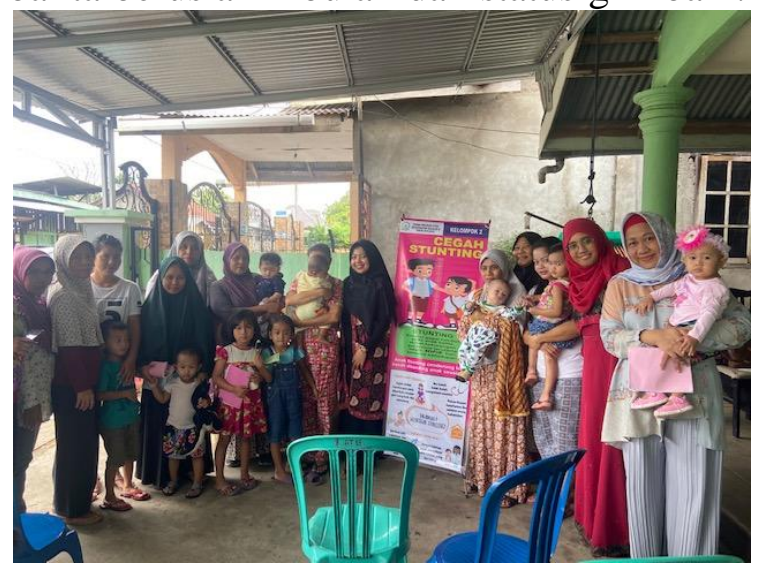

Gambar 1. Kegiatan edukasi

b) Edukasi Ibu dan balita mengenai tumbang

Menurut Depkes (2010), pemeliharaan status gizi anak sebaiknya:

1. Dimulai sejak kandungan. Ibu hamil dengan gizi yang baik, diharapkan akan melahirkan bayi dengan status gizi yang baik pula

2. Setelah lahir segera beri ASI ekslusif sampai usia 6 bulan

3. Pemberian makanan penamping ASI (weaning food) bergizi, mulai usia 6 bulan secara bertahap sampai anak dapat menerima menu lengkap keluarga.

4. Memperpanjang masa menyusui (prolog lactation) selama ibu dan bayi menghendaki

Selama kegiatan tim pengabdian masyarakat memberikan pengertian dan edukasi kepada ibu balita bahwa pentingnya mengetahui dan memelihara status gizi balita.

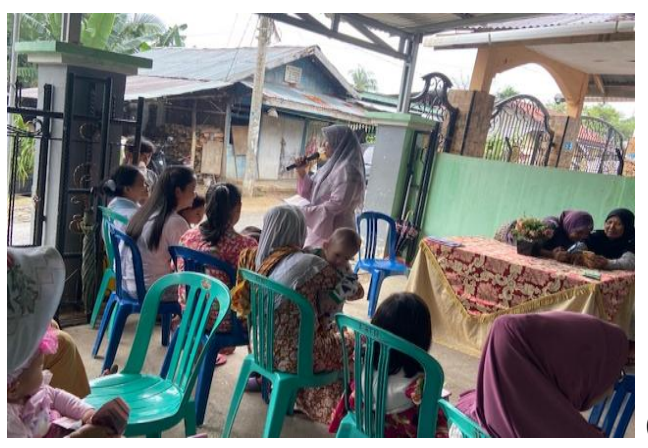

(2)

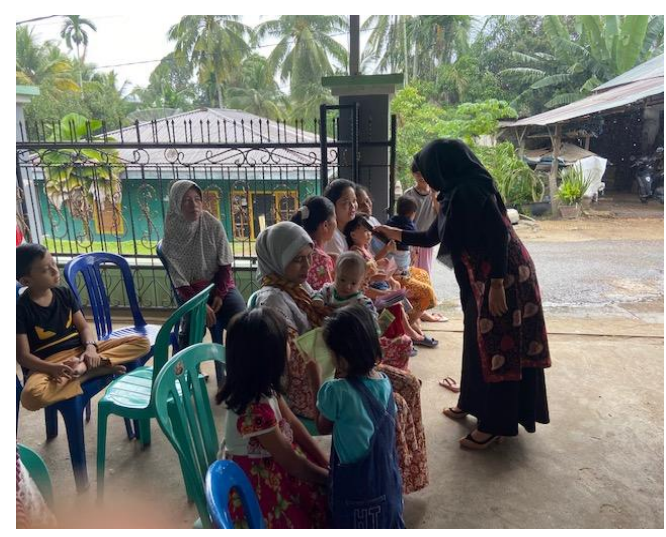

Gambar 2 dan 3. Kegiatan edukasi

Selain itu tim pengabmas juga memberikan penjelas bahwa masa anak di bawah lima tahun merupakan periode penting dalam tumbuh kembang anak karena pertumbuhan dan perkembangan dasar yang berlangsung pada masa balita akan memengaruhi dan menentukan setiap perkembangan anak selanjutnya( Depkes RI,2010). Tumbuh kembang merupakan proses yang berkesinambungan yang terjadi secara konsepsi dan terus berlangsung hingga dewasa (Sujiono, 2008). Selain mengalami partumbuhan fisik yang pesat, perkembangan kemampuan otak juga penting untuk proses pembelajaran dan pengayaan perkembangan kecerdasan, keterampilan motorik, bicara dan bahasa, serta sosial dan kemandirian. Anak dengan status gizi kurang akan mengalami perkembangan yang terhambat dan tidak optimal sesuai dengan tahapan usianya, sehigga memicu terjadinya stunting pada anak (Depkes RI, 2010) .

Stunting menjadi indikator kunci dari kekurangan gizi kronis, seperti pertumbuhan yang melambat, perkembangan otak tertinggal sehingga anak stunting lebih mungkin mempunyai daya tangkap yang lebih rendah. Tim menegaskan bahwa masa tumbuh kembang balita sangat menentukan karena menjadi dasar terbentuknya manusia seutuhnya. Karena itu pertumbuhan dan perkembangan saling mendukung satu sama lain. Perkembangan seorang anak tidak dapat maksimal tanpa dukungan. Seorang anak memerlukan perhatian khusus untuk 
optimalisasi tumbuh kembangnya. Optimalisasi perkembangan diperlukan seperti adanya interaksi anak dan orang tua, terutama peran ibu yang sangat bermanfaat bagi proses tumbuh kembang anak secara keseluruhan. Orang tua dapat segera mengenali kelainan proses tumbuh kembang anak sedini mungkin dan memberikan stimulasi yang menyeluruh, baik aspek fisik, mental, sosial dan kemandirian.

Pada fase kehidupan anak terdapat fase pertumbuhan dan perkembangan. Tumbuh kembang anak sangat dipengaruhi oleh kecukupan nutrisi. Kebutuhan nutrisi anak yang tidak terpenuhi menyebabkan anak akan mengalami kelainan gizi. Akibatnya, anak menjadi mudah terserang penyakit, pasif, mudah letih, lesu, mengantuk, tidak dapat menerima pelajaran dengan baik yang menyebabkan prestasinya akan berkurang (Kemenkes RI,2013).

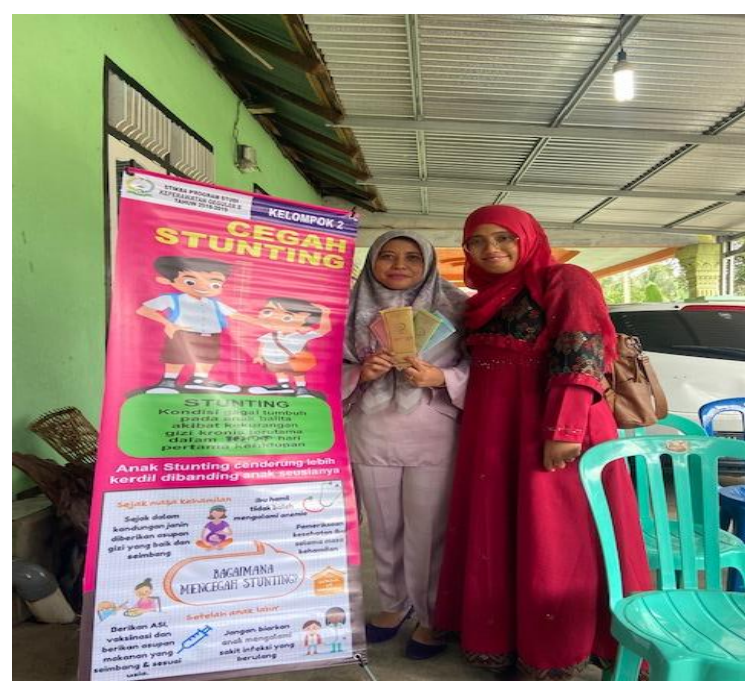

Gambar 4. Pemberian Banner

Selain itu, kekurangan gizi pada balita merupakan salah satu masalah kesehatan yang bisa berdampak pada kematian. Faktor status gizi menjadi hal penting yang harus diperhatikan untuk membantu perkembangan anak, khususnya di masa balita (soedjiningsh,2010).

Perkembangan motorik dan bahasa sangat dipengaruhi oleh status gizi, status kesehatan, dan stimulasi gerak dan bahasa yang sesuai dengan masa perkembangannya. Gizi kurang akan menghambat laju perkembangan anak. Akibatnya, proporsi struktur tubuh menjadi tidak sesuai dengan usianya dan berimplikasi pada perkembangan aspek lain. Apabila anak balita mengalami kurang gizi akan berdampak pada keterbatasan pertumbuhan, rentan terhadap infeksi, dan peradangan kulit.

Akhirnya, perkembangan anak yang meliputi kognitif, motorik, bahasa, dan keterampilannya akan terhambat dibandingkan dengan balita yang memiliki status gizi yang baik" Status gizi kurang akan memengaruhi perkembangan mental maupun sosial anak. Oleh karena itu, keduanya harus mendapat perhatian, baik dari pemerintah, masyarakat maupun orang tua. Salah satu indikator untuk melihat pertumbuhan fisik anak adalah dengan melihat status gizi anak. Sebagai alat ukur untuk mengetahui tingkat perkembangan seorang anak dengan menggunakan kartu menuju sehat (KMS) (Kemenkes RI,2013).

Prevalensi gizi kurang dan buruk yang tinggi berdampak pada terjadinya stunting pada balita. Tiga faktor utama penyebab gizi kurang, yaitu kualitas dari kuantitas konsumsi pangan yang buruk, pola asuh, dan akses fasilitas kesehatan yang tidak memadai. Faktor yang berkaitan dengan stunting, yaitu, status sosial ekonomi keluarga, pendidikan orang tua, status gizi, berat badan saat lahir, penyakit anak, persediaan air bersih, pelayanan kesehatan, dan etnis(Mgongo).

c) Evaluasi Kegiatan Pengabmas

Usai memberikan edukasi dan penyuluhan tim pengabmas memberikan post test, dimana hasil dari post test tersebut ibu balita diberikan cindramata.

\section{KESIMPULAN DAN SARAN \\ 1. Kesimpulan}

Semua balita termasuk dalam kategori gizi baik, Ibu balita akhirnya mengetahui pentingnya pengukuran pertumbuhan dan perkembangan balita, ibu 
balita mengetahui pentingnya mencegah stunting pada masa balita.

\section{Saran}

Kegiatan pencegahan stanting perlu juga dilakukan tidak hanya dalam pengukuran pertumbuhan balita, namun juga perkembangan balita.

\section{UCAPAN TERIMAKASIH}

Terima kasih kepada Kepala Puskesmas Putri ayu, Bidan Bagian Tumbang Puskesmas Putri Ayu, Ibu Kader, serta Ibu Balita yang hadir.

\section{DAFTAR PUSTAKA}

Departemen Kesehatan RI. Buku Kesehatan Ibu dan Anak Gerakan Nasional Pemantauan Tumbuh Kembang Anak. Jakarta: Departemen Kesehatan RI; 2010.

Grantham S, Cheung YB, Cueto S, Glewwe P, Richter L, Strupp B. Development potential in the first 5 years for children in developping countries. Lancet 2007;369:60-70.

Kementrian Kesehatan RI. Laporan hasil riset kesehatan dasar (Riskesdas) Tahun 2018. Jakarta: Kemenkes RI; 2018.

Kementrian Kesehatan RI. Laporan hasil riset kesehatan dasar (Riskesdas) Tahun 2013. Jakarta: Kemenkes RI; 2013.

Mgongo M, Katanga J, Uriyo JG, Damian DJ, Stray-Pedersen B, dkk. Predictors of appropriate breastfeeding knowledge among pregnant women in Moshi Urban, Tanzania: a cross-sectional study. Int Breastfeeding J 2017;11:1-8.

Notoatmodjo, S. Promosi Kesehatan \& Ilmu Perilaku. Jakarta: Rineka Cipta; 2007

Soetjiningsih. Tumbuh kembang anak. Jakarta: ECG. Penerbit Buku Kedokteran; 2010.

Suherman. Perkembangan anak. Jakarta: EGC; 2010.

Supriasa, dkk. Penilaian Status Gizi, Jakarta: EGC; 2001 